\title{
Representation of Women in Early Indian Movies: A Study of How Indian Culture is Translated into Visual Texts
}

\author{
ANWITA MAITI \\ UDAYA NARAYANA SINGH
}

\begin{abstract}
The paper focuses on five Indian movies created during the era of 1930 till 1960 which were realistic visual texts, in comparison to present day Bollywood movies that are bordering on being unrealistic rendering of stories. The movies of yester-years, often made from the fictional work that had made an impact, talk about social situations and place of women in those contexts. They show what women do when faced with predicaments and give us practical and reasonable solutions which were feasible in those times. The realistic nature of these works of fiction into films is a feature that still draws people's attention towards them, so that they learn how to face and confront the truth and the stark realities. As one notices the Bollywood and Bollywood inspired movies across other Indian languages and spaces took a turn to move away from reality to place the audience in a world of imagined phantasmagoria to please them. How visual texts could be turned into extremely heinous and delusional objects could be gauged from these later films. These early era movies contribute to the emancipation of women in a significant manner and do not treat women as merely enticing objects.
\end{abstract}

Keywords: Representation of Women, Early Indian Cinema, Screen Space, Visual Texts, Story-line. 


\section{Introduction}

The film directors in the 1930's, 1940's and 1950's had selected works of fiction as their natural base to convert them inter-semiotically to write their screenplays and upheld women's causes with a great empathy. They had given ample screen space to their women subjects and focused towards the women protagonists in the stories they would weave. Knowingly or unknowingly, the movies had shown streaks of feminism in nature. The regard and consideration that most of these eminent directors had given to women, was far more progressive than the way these subjects are treated even today. These movies evoked positive reactions among people as they saw their known or read stories come alive through a kind of transference. To think about women and their well-being, or to consider that a woman should be heard, just as the men-folk are listened to, have been the strong points of these visual texts. The movies drew attention towards women's causes without even having to try hard.

A comparison of the olden days' movies with todays' movies becomes necessary to show the vacuum in the story-line followed by the present-day film makers. The effect of many literary personalities joining the film industry in both Kolkata and Mumbai had made a lot of difference in the choice of texts. In comparison, the popular commercial movies in current times are still sexist in nature to a large extent and they shamelessly disparage women.

On comparing directors from the olden days and the presentday film makers, one might wonder as to why movies from the 1960's onwards, started severely disrespecting women, thereby taking them back to their dark times. Is it because the great works of fiction are not getting rendered into films anymore? Is it because the society feels threatened to see women as liberated and educated with minds of their own? Is it because 
Representation of Women in Early Indian Movies:...

the fourth estate, or the print media, has become very vocal these days on women's issues? The patriarchy, that opposed allowing a level-playing field for the "so-called" weaker sections of writing against emancipation of women even when similar topics or subjects were taken up by the novelists such as Saratchandra Chattopadhyay or Rabindranath Tagore.

If we go back in time to study the older commercially successful movies, one could see how positively women were represented during this era and one might want to learn from them about how much respect they have given to their women protagonists. The olden days' characterization of women as well as situations where their voices would be heard did the trick. What comes to notice is also that the screen space given to women actors is much wider, as they stood alone without reference to a man or men in the story. Compared to them, todays' women either stand at the edge of the screen or appear to be squeezed into some greater space only to commodify them in bold scenes. Also, every olden day-movie has had a message to convey which the women protagonists put forth strongly, either vocally or silently through their body language, but nevertheless they made themselves heard. While in the present day Indian society in the twenty first century, we call ourselves modern, one might wonder why is there still such a dissonance or disagreement as to how women's representation on screen should be, where they shall be seen as independent and bold and how women are actually represented on screen. The modern movies seem to re-glorify all the ill practices of society which early Indian movies were trying to eradicate.

\section{Texts and Discussion}

Our discussion will include five Hindi movies which are Achhut Kanya (1936), Duniya Na Mane (1937), Aurat (1940), Ziddi (1948) and Pyaasa (1957). In what follows, we will discuss the background information of each movie followed by 
their thematic treatment of women's issues. These movies of early Indian cinema came into fruition through the efforts of pioneering directors like Franz Osten, V. Shantaram, Mehboob Khan, Shaheed Latif and Guru Dutt. That, early Indian Cinema was respectful towards women and made their opinions being heard, are very evident in these chosen five movies. The women protagonists speak their minds without ever seeking for approval or consent from men on whether they should speak, or at least they do not seem to be asking men to guide them through their life's path or to be their decision makers. It is very perplexing, as to why, from being independent and headstrong, women have gradually begun to be shown as meek, coy and submissive, in later Indian cinema.

\subsection{Achhut Kanya (Untouchable Maiden), Franz Osten, 1936}

Achhut Kanya (Untouchable Maiden), a 142-minute movie released in 1936, is one of the earliest super-hit films of the Bombay Talkies ${ }^{1}$. The movie was made through the joint efforts of Franz Osten, Niranjan Paul and Himanshu Rai, where, Franz Osten was the director, Niranjan Paul was the screenwriter and Himanshu Rai the producer. Saraswati Devi sung the songs, which were written by lyricist J. S. Kashyap. The movie had Devika Rani and Ashok Kumar in its leading roles. The movie fearlessly showed the caste system ${ }^{2}$ prevailing in India in a poor light, where people were being divided on a pointless basis. Here, lovers Pratap (Ashok Kumar) and Kasturi (Devika Rani) were shown as childhood

${ }^{1}$ Bombay Talkies was a Film Studio founded in 1934 by Himanshu Rai and Devika Rani, which produced seminal, path breaking movies that often had a social message to convey. The industry produced about 40 movies during its existence and the last film was made in the year of 1954 .

${ }^{2}$ Casteism is a practice in Hindu society, where people are stratified into four major castes which accordingly from higher to lower hierarchy are Brahmin, Kshatriya, Vaishya and Shudra. 
friends, even though the boy was a Brahmin and Kasturi was an achhut (modelled after the Sanskrit word, asprishya) or untouchable. How hollow the social conventions of the time were come out clearly through the story-line when Kasturi sacrifices her life in trying to save both her husband Manu and her former lover, Pratap.

A pioneering playwright, Niranjan $\mathrm{Pal}^{3}$ (1889-1959) seems to have written the popular story 'The Level-Crossing' and also for the film screenplay. A December 10, 2001 review of the movie in the Times of India ${ }^{4}$ says that the movie shown by Franz Osten had screened the movie in Berlin at Goebbel's Ministry of Propaganda in Nazi Germany where it was wellreceived. In fact, such fiction writers as Pal has not been discussed much except in the Kusum Pant Joshi book - partly an autobiographical work by Niranjan Pal who was the oldest son of nationalist leader Bipin Chandra Pal and like his father, was influenced by revolutionary ideologies. He was sent to London to avoid arrest as he snatched a revolver from a Scotsman in Calcutta. In London too, he got into trouble being in the company of freedom fighter Veer Savarkar. By 1913, he began working with Kent Film Company and also started his literary career. ${ }^{5}$ In fact, Pal had established himself as a playwright by 1910 with his two successful plays - The Light of Asia and Shiraz, staged in London. The German filmmaker Franz Osten was attracted to these and made silent films out of these, in which the lawyer turned film-maker Himanshu Rai had also acted. He made directorial attempts with Needle's Eye (1931), Pardesia (1932) and Chitthi (1941) but was in fact,

\footnotetext{
${ }^{3}$ See Joshi, Kusum Pant () Niranjan Pal: A Forgotten Legend \& Such is Life.

${ }^{4}$ http://timesofindia.indiatimes.com/articleshow/1198164865.cms?utm_sour ce $=$ contentofinterest\&utm_medium=text\&utm_campaign=cppst

${ }^{5}$ Sahani, Alka. 2012. 'Such is Fame.' Retrieved from http://archive.indian express.com/news/such-is-fame/917431/
} 
much more successful as screenplay writer in Achhut Kanya (1936), Janmabhoomi (1936), Jeevan Naiya (1936) and Jawani Ki Hawa (1935) - all of which had shown rare class and moral values. The theme of Jeevan Naiya had to do with ostracism of dancing girls which was a courageous topic to choose. The literary background of Niranjan Pal had made the transition of his short story into film in Achhut Kanya very special.

In the film version, we find Kasturi, a young Dalit ${ }^{6}$ girl and Pratap, a young Brahmin boy are childhood friends who are lovers. Kasturi's father, a railway signalman saved Pratap's father's life, a grocer, when he was bitten by a snake. Since then, the two men become good friends, despite differences in their caste status. Though a grown up Pratap's mother is not in favour of him openly roaming around with Kasturi in the village, as they used to do in their childhood, Pratap's father does not seem to mind the two young people being seen together as he still believes they are just like old friends, not realizing that their bond of friendship has turned into a bond of love. When the villagers sense a relationship growing between the two and start scheming against what they think will be an ominous marriage between a Dalit girl and a Brahmin boy, because it will go against the social custom. ${ }^{7}$ The parents from both sides try their best to separate the two young lovers since the possibility of a marriage between them would be almost impossible. Even though the parents, the two fathers wished for the young lovers to get married, they were not brave enough or willing to defy society's rule where inter-caste marriage is forbidden. In order to stop village people from

\footnotetext{
6 Dalits are and were treated as untouchables in India, since they belong/belonged to a lower hierarchy in society.

${ }^{7}$ Inter-caste marriage was forbidden and is still forbidden (in many regions) across India.
} 
further speculation and, in order to set apart the lovers, to make them forget each other, Pratap's parents and Kasturi's father, where she is a motherless child, agree unanimously that the two young people should be married off to other people (within their respective castes) immediately. While Pratap's mother is not willing to an inter-caste marriage, otherwise, she is seen as very progressive in her outlook as she is not willing to take dowry money ${ }^{8}$ from the girl's family, for her son's marriage. Pratap's father on the other hand is seen to be waiting with the plan that the dowry money that he could gather from his son's marriage shall be given to his friend, so that Kasturi's marriage can be soon fixed where there shall be no dearth of dowry. Pratap gets married to Meera and a little later, the film, reveals that Kasturi is already married to Mannu, since in their childhood they were married where Kasturi's father and Mannu's father were friends. The two unisons prove to be a bad match as Pratap and Kasturi are still very much in love with each other and they cannot develop feelings or emotions towards their respective spouses. Their spouses are unhappy too, and so are Pratap and Kasturi deeply tormented and distressed as they are shown to be feeling guilty for their spouses, to whom they cannot reciprocate their love. Meera, Pratap's wife, who tries to be an ideal Indian wife by aiming at pleasing her husband to the utmost, does not understand why Pratap looks so depressed and forlorn in his marriage. Soon, she realizes that he loves somebody else and Pratap too confesses that he was pressurized into a marriage with her, and that, he still loves the untouchable girl Kasturi. Meanwhile, Kasturi, whose marriage to Mannu gets resumed,

\footnotetext{
${ }^{8}$ In Indian marriages that held in a Hindu society, the bride's family needs to pay lump sum dowry money to the groom's family, in order to marry off their daughter. Though The Dowry Prohibition Act has been passed in 1961, in de jure, but dowry is still being practiced in de facto.
} 
has to face his first wife who comes to live with them whom Mannu deserted because of her family's too much interference in their marriage, but he reluctantly accepts her back when Kasturi welcomes her as her elder sister. With Pratap's wife eyeing for her husband's love and with Mannu's first wife jealous of seeing Mannu preferring the beautiful Kasturi over her, the two bitter and angry women feel betrayed and they unite together to take revenge against Kasturi, in some or the other way round, as they launch a plan to prove that she is a licentious and a promiscuous woman. Kasturi, who is otherwise kind-hearted and friendly towards the two women, go to a village fair with them, where the two women desert her and she is left alone in the fair, at night, not knowing how to return home. Pratap, who is also present in the fair, selling goods, sees a distressed Kasturi and takes her back home in his cart. Meanwhile the two women reach home and try to enrage Mannu, by giving him the impression that Kasturi is with somebody else. As Mannu spots Kasturi and Pratap coming towards their home, seated together in the cart, he gets vexed and tries to kill Pratap as he believes Pratap tried to lure Kasturi and hence they are seen together. In the midst of all chaos, emotional torment and unhappiness, when Pratap is attacked by Mannu, in order to save him and also to divert Mannu's focus and distract him and also to release herself from all emotional pain that has been engulfing her ever since the lovers were separated, Kasturi jumps on a moving train and kills herself. Later, the film focuses on an epitaph of Kasturi, at the same railway station, where village people revere her for sacrificing her own life for others' good. Kasturi saved Pratap by killing herself and also released herself from the pain of never being able to be with Pratap. Not to forget, she also wanted to do good for the other two women as well, since she always felt guilty as they had to be entrapped in marriages 
where their spouses did not love them because both Pratap and Mannu were madly in love with her.

The film protests against the pointless, illogical and meaningless tradition of Casteism that is practiced among the Hindus in India, which have been darkening the society since ages, where social stratification and countless divisions among people, only bring about more misunderstandings and hostility, where instead of uniting; they decide to become severely divided, owing to which nothing effective and constructive can be done in the country where people can work holistically in unison. Casteism is rife and it overrides basic rights of human beings, where more than food, clothing and shelter, the first thing that people would like to know is who belongs from which caste. Kasturi and Pratap, who should otherwise have been happily married, were forcibly married to other partners, who also had to suffer the consequence because they were trapped in loveless marriages. Meera was tormented to realize and hear about her husband's declaration of love for someone else and Mannu, who became possessive of Kasturi and was head over heels in love with her, could also feel her mind drifting somewhere else, in a different world where she is longing for someone else. The two marriages not only destroyed Kasturi's and Pratap's lives, but also equally that of Meera's and Mannu's lives as well. Also, what comes to notice is how a woman has been a "self-sacrificer", in this movie, that is also reflecting the Indian society where women receive more positive adjectives when they decide to live life for others and not for themselves. In order to make peace and make Pratap's life happy, Kasturi kills herself. She wants Pratap to live in peace so she jumps in front of a moving train. Indian society has the propensity to celebrate themes on a woman being a self-sacrificer, where she would easily give up on her life, for the sake of a man. It is often very rare that it is seen, a man sacrificing life for a woman, but it is readily assumed that 
women were born to serve men and to make them happy, that these are the only purposes of their lives where everything that they do is only for men's well-being. From sacrificing life in Sati $^{9}$ for the husband, sacrificing life for family and sacrificing life for a lover, Indian women have been sacrificing for way too long. The question remains, can Indian movies not compromise or do without themes where women are sacrificing lives for others and rather cerebrate on alternative solutions where women get to live? Because, from the 1930's to the present times in 2018, no matter how much they proclaim they have become progressive and liberal, Indians are still hell-bent on seeing a woman "sacrificing" her basic rights, wishes and desires for the sake of a man.

\subsection{Duniya Na Mane (The Unexpected), V. Shantaram, 1937}

Duniya Na Mane (The Unexpected), a 148-minute film was directed by the notable Indian film maker V. Shantaram (19011990), or Shantaram Bapu, a Marathi film actor-directorproducer with a number of excellent and popular films such as Dr. Kotnis Ki Amar Kahani (1946), Amar Bhoopali (1951), Jhanak Jhanak Payal Baaje (1955), Do Aankhen Barah Haath (1957), Navrang (1959), before he made Duniya Na Mane (1937). In 1929, he and his friends set up 'Prabhat Film Company' but by 1942, he established 'Rajkamal Kalamandir' - a sophisticated film production house. This film was first made in Marathi with the title 'Kunku' (1937). The lead actress, Shanta Apte not only gained immense popularity for

${ }^{9}$ Sati was a practice held in Hindu society, more rigorously in the higher castes, where the widow of a dead man was pushed into self-immolation by burning her in the funeral pyre with her deceased husband, with the intention and the assumption that she could accompany the man in his afterlife to give him company. 
her depiction of this strong woman character but she also sang the songs in the movie. It even included a full-fledged English song titled "A Psalm of Life", written by Henry Wadsworth Longfellow. The movie became a commercial success and received adulation from critics who held it as a bold movie that undauntedly attacked the mistreatment of women in the Indian society. The film was specially focused on child marriage, an immoral custom that was being practiced those days.

The story was based on the novel Na Patnari Goshta written by the popular Marathi writer Narayan Hari Apte, who also wrote the screenplay of this film. Directed in the 1930s when India was striving for her own Independence, this movie gives women their voice of anger to protest. The protagonist, Nirmala not only protests for herself, but also for countless of other women who were married off to old men - a normal practice in India at that time. Nirmala's protestation also awakens her husband. There is a very young girl who is made to become aware of the dangers she would face when she grew up. Nirmala also alludes to the girl that a woman who is truly happy in her marriage puts sindoor on her forehead readily on her own will. The message that goes off from Nirmala to the audience is that a young woman, who is forcibly tied in an unsuccessful, stifling and purposeless marriage to an old man, is forcibly made to put sindoor on her forehead, by society. Nirmala is also supported and encouraged by the social reformer's daughter, who had the courage to confront her father into making him realize how he destroyed a young woman's life through his power of money. On the other hand, Nirmala has to face the lawyer's aunt, who is a pest to the society because while as a woman she should have come to Nirmala's help, she disagrees with Nirmala's protestation. She rather deems her to be too opinionated as an Indian woman. She wants Nirmala to be meek, coy and submissive woman, mainly to be of service to her nephew. Such women like the 
judge's aunt are blinded by tradition and custom and make it a point to mould every woman into a patriarchal society's expectations and fit them in the rule books that are made for women to adhere to. The husband, the old man has an awakening finally as he realizes where he accepts and admits his fault, even though it is too late because Nirmala's life has been damaged enough already, which cannot be undone.

Narayan Apte wrote novels and collections of short stories. He was influenced by the ideas of social reform movements of the $19^{\text {th }}$ century in Maharashtra. His stories cover historical and social themes, which are based on the everyday life of the Marathi middle class. He had travelled extensively throughout India and Nepal and picked up the languages - Hindi, Bengali, Gujarati, Nepali and English. Apte stayed at Jaipur (Rajasthan) and taught in a school there. The background of the authortranslator makes it very clear as to his socio-political stand. The movie was screened at the Venice International Film Festival and had Shanta Apte in the lead role -both acting and singing. As a traditional Hindu moralist, Apte did edit and publish essays and stories to promote life with high value. He was a co-editor of Kirloskar Khabar and had also started a literary and political journal named Aalhaad by 1915 and later, another magazine named Madhukar. He founded a book publishing house, Ajinkyatara Pustkalay in 1913 and later "Apte \& Co" in 1924. He also started a printing press, Shriniwas Mudranalay (1920). Such were the authors who were involved in the making of Duniya Na Mane.

The thematic details of the movie show a poor young orphan woman being married off to a rich elderly lawyer, who is old enough to be her father. The old man has a widowed daughter and a son, who are all around the age of his newly 'acquired' wife, Nirmala. When the prospective groom's party shows up at Nirmala's uncle's house, the lawyer comes accompanied by 
a young man, whom Nirmala assumes to be her future husband and hence shows no hesitation as she finds him young and appealing. Later, on her marriage day, when she is about to put garland around her husband's neck and sees his face for the first time; she becomes horrified to discover that her husband is the old man who accompanied the young man before; when they came to see her. She protests immediately, but her uncle rushes into the scene and forces the marriage to resume, after a little turmoil. Later, from her little cousin, Nirmala learns that she was tricked into marrying the old man and it was cleverly planned so that the young man would accompany him to give her a false impression that would make her happy. Later it becomes clear that she was forced into such a marriage by her greedy uncle who in return wanted money and favours from the old lawyer. It was almost like selling his young, innocent and beautiful niece. Abandoned and helpless, Nirmala had to acquiesce to what has been decided for her. But before leaving for her husband's house, she strongly protests against this trickery. She also forbids her uncle from taking his entire family to follow to the lawyer's house with Nirmala, as was decided as a stipulation between the uncle and the lawyer. Through this, Nirmala further realizes how she is used as a "bait" and "barter of exchange" because of her uncle's own self-centeredness and greed on the one hand and as an object of physical and sexual pleasures at his old age. A forced Nirmala is dragged to her husband's house where she feels no interest to start life anew as a married woman. She does not take part in sharing domestic chores, but lives in an isolated room where she avoids her husband and his aunt, who constantly nags her, chides her and pressurizes her to perform the duties of an 'ideal Indian wife'. She wants Nirmala to work day and night, be in constant service to her husband and do what he commands. Since Nirmala is young and is not willing to get into any kind of physical relationship with the 
old man, his aunt plays an indecent trick where she locks up Nirmala in her husband's room and sends in her nephew to make use of the opportunity. Nirmala fathoms the cruelty and dirtiness of such an act but maintains her calm composure and the old man loses at the end where he retreats.

Often, throughout the movie, one can hear Nirmala alluding to the fact that how, despite being an old man and a widower with two children who are around her age, with the daughter being elder to Nirmala and the son around her age, his sexual needs are still not appeased as he wants more carnal pleasures by exploiting and depriving a young woman who should never have been his wife in the first place. The old man, however, refuses to accept that he is old and instead, constantly tries to prove his virility. He keeps using dyes for his hair and moustache to prove he is young in both heart and in body. Through these harrowing times, Nirmala nonetheless tries to keep herself cheerful and occupied by interacting with a young girl who lives in the lawyer's house and calls him chacha (uncle). Together with her, Nirmala grows a garden at their house, where they dance and sing. Nirmala soon turns the empty, dead and lifeless house into a beautiful paradise. Through Nirmala, the young girl slowly realizes the ugly side of marriage and the ill fate of Indian women. When the lawyer's social worker, widowed daughter comes home for Diwali, Nirmala becomes energetic and happy to see such an inspiring and educated woman and decides to open her mind to her about her cruel fate. The daughter does not concur with her father's second marriage and she feels for Nirmala, that such a young woman's life has been ruined as her father forcibly married her for his own sexual needs. As the film unfolds, it is seen that the daughter earlier wrote a letter to her father pleading with him not to marry a poor young girl for his own enjoyment, to which he paid no heed. On seeing a very young 
Nirmala for the first time, she becomes startled and astonished, almost disbelieving the crime that her father has committed. She tries to confront her father, but having been shaken because of his own guilt, he dodges off with excuses. Towards the end of the movie, the man starts feeling really guilty and mumbles and calls himself burha (old man).

Aside from his daughter, the viewers also see that Nirmala is teased by the lawyer's stepson who passes sexual remarks. The lawyer tries to stop his son, but he fails and gives up. Nirmala realizes that the son is spoiled, and that the old man no longer has the strength to tackle his grown-up son. So she takes decisions in her own hands where she confronts her stepson and flogs the young man like she should as stepmother and ultimately makes him fall at his father's feet where he is asked to seek forgiveness. After this incident, on seeing Nirmala's sense of justice, rationality and strength, the lawyer has a moment of awakening of his conscience. He realizes that he has been blind to the ways of society and its customs, which are gravely unfavourable towards a woman. The last turning point in the story-line appears when we see him freeing Nirmala from her bondage by removing the mark of sindoor ${ }^{10}$ from her head, thereby declaring her as his daughter instead. Puzzled and confused, at first Nirmala cries and rushes to her husband and asks him to take her back, but for the first time in the movie, the man talks to her like his daughter and agrees that theirs is a very wrong match indeed, because a young woman needs a young man to make her happy. He feels extremely guilty that while his old heart yearned for a company, he ruined a young woman's life and society accepted it and considered it to be normal.

\footnotetext{
${ }^{10}$ Sindoor is a Hindi word which implies the red mark that a married Hindu woman needs to put on her forehead to signify that she is married.
} 


\subsection{Aurat (Woman), Mehboob Khan, 1949}

Aurat (Woman), a 1940, 154-minute movie, was directed by Mehboob Khan and written by Babubhai Mehta and Wahajat Mirza. With Sardar Akhter in the lead role, the movie talks about how a woman, a single mother who is deserted by her husband, resolves to take care of her three sons and her mother-in-law. The story-line of Aurat opens with Radha, a poor farmer's wife, toils hard day and night to keep her husband, three little sons and mother-in-law in good health and spirits. This indomitable woman called Radha braving numerous hurdles in life to raise her three sons and also to pay off debt to Sukhilala, the moneylender, who is notorious for mistreating women. When faced with abject poverty, owing to crop failure, her husband deserts his family and she takes up the sole responsibility of taking care of them. Initially, she feels helpless and breaks down, but then resolves to fight, to make her mother-in-law and three sons survive through her struggle. Her husband Shamu runs away to avoid responsibility when she becomes pregnant again, leaving her to fend for herself against poverty and the lecherous advances of Sukhilala. Her mother-in-law succumbs to death and one of her son falls ill and dies as she fails to gather enough money for his treatment. Shattered, Radha realizes that in order to save the lives of her other two sons, she needs more money and sees that the only way she could bring economic upliftment to her family, is by acquiescing to the demands of the moneylender, who wants her body for his sexual pleasures. In penury, with constant thought of how to raise her sons and give them a secured future, Radha finally sells her body, though she is deeply hurt and agonized but has no other way round.

The movie was remade in Mother India (1957) by the same director, which became one of India's most popular Hindi 
cinemas of all times. Babulal Mehta began as a screen writer in 1937 with his story Jagirdar, where we find Neela marrying Jagirdar Surendra who secretly marry and have a child. In a shipwreck, the Jagirdar is believed to be dead, and the cruel patriarchal society considers the child to be illegitimate. Eventually, a poor farmer Shripat marries Neela and brings up her son Ramesh. The trouble begins when the supposedly dead husband returns and violently quarrels with Shripat as to who 'owns' Neela. How women are viewed and valued in traditional societies comes out clearly here. Finally, of course, we find the villain Banwarilal killing poor Shripat and framing Neela's husband for this murder. The real tension is around the fact that Neela's son rejects Jagirdar as his "real" father, until both father and son duo confront the gangsters in Narayanlal's den.

Mehta's next film story, Tin sau din ke baad (1938) is a fantasy and adventure film, where the story revolves around a millionaire who enters into a bet with his doctor that he will go out into the world without taking any money and survive for 300 days. But right from his next film, Ek hi rasta (1939), Babulal Mehta shows a lot of courage as he depicts a couple living together as the main female protagonist, Mala, stubbornly rejects the pressures of her stepmother and overtures of her villainous cousin Madan, to live with Raja who gives her shelter as she is able to escape from the clutches of a sex tradesman, Banke who sold her to a rich man.

In Aurat, Radha goes through both economic and emotional crises in the movie. The question remains, why is she alone being blamed for Birju's behaviour? Why did not the villagers otherwise decide on punishing Birju collectively? Though Radha did love Birju dearly and pamper him despite seeing him getting engaged in wrong activities, Birju nevertheless was already a grown up man, an independent person with his own bad personality, for which Radha alone is not culpable. 
Both Radha and society are at fault in this regard. Radha blindly loved and trusted in her son, which is very innate of most Indian mothers who see their sons as gifts from God and refuse to find any fault with them, but the villagers should not have blamed Radha for Birju's behavior because, should a dacoit's ${ }^{11}$ mother only be blamed for his murdering of people and looting of their properties? The villagers are enraged with Radha and they put complete fault on Radha for pampering her son way too much and not disciplining him. Finally, when Birju goes to the severe extreme and abducts a young girl from the village, Radha shoots him to save the honour of her family and also to save the girl from being kidnapped and carried away.

One aspect of the film that should not be overlooked is the issue of son worshipping in India. Everybody demands and forces the mother to bear a son in the society, as if that destiny and biology are in her hands, where she has the power to give birth to a son. In the movie, after the birth of her third grandson, the mother tells her son that the birth of three sons would do good for the family, where they shall be showered with economic prosperity, but her son reminds her that she had the same high hopes when the first boy was born, and ever since then they have been becoming only poorer.

The time since the movie was made in the 1940's, till present times in 2018, so far now, the Indian society has still not been able to overcome from the obsession of "son worshipping" from their hearts. But the movie is also exemplary in the regard that the mother no longer concurs with her son's illegal and harmful activities and finally kills him in her own hands, because of the uncontrollable monster he turned into, where he wreaked havoc and ruined people's lives. Despite being a mother, she has the strength and rationality to no longer allow

${ }^{11}$ Dacoits - in India armed robbers are called dacoits. 
her son to keep up with his anti-social activities. Also, coming to Ramu, one might question as to how can he so easily, remain unperturbed regardless of knowing that his brother openly flirts with his wife and also exercises his rights by hitting her and flogging her whenever he wishes? Why didn't Ramu stand up for his wife? Is a wife just a common property that can be used and exploited by everyone?

\subsection{Ziddi (Stubborn), Shaheed Latif, 1948}

Ziddi (Stubborn), a 1948, 122-minute movie, is based on a novel by the same name, written by the pioneering Indian writer Ismat Chughtai (1915-1991) and directed by her husband Shaheed Latif. The movie talks about how a rich man remains resolute in marrying a poor woman whom she loves, and how others, who initially do not concur, later help him as he gets to meet his lover, to finally marry her. The film introduced the new actors Dev Anand, Kamini Kaushal and Pran in Hindi films, where the notable singers Kishore Kumar and Lata Mangeshkar recorded their first duet "Yeh Kaun Aya $R e$ ". Chughtai was a major voice in Urdu literature and was also well-known for her stories on female sexuality and femininity, middle-class gentility and class conflict. Her shortstory Lihaaf ("The Quilt", 1942) focuses on sexual awakening of Begum Jan following her unhappy marriage with a nawab. She had to face a court trial for her hints at female homosexuality there. The charges of "obscenity" notwithstanding, she went on creating woman-centric fictions that got translated into film by her husband, himself a dialogue writer for Hindi-Urdu films of those days. Obviously, her portrayal of the insulated life of a neglected wife in the feudal society is not something that would be liked by the patriarchy then or even now. Further, Chughtai was so liberal that her daughter, nephew and niece were all married to Hindus and for her the peaceful comingling and living of Hindus, Muslims 
and Christians in India defined her cultural space. She said she read not only the Qur'an, but also the Gita and the Bible with an open mind. It is obvious that when such works of fiction get rendered into films, the effect on the psyche of the masses is different. These promote tolerance and harmony as well as remove imbalances against women.

In the movie's story-line, we find Puran, a wealthy man who does not believe in class distinctions, falls in love with Asha, a poor woman. Puran's uncle loved Asha's mother, who worked as a maid servant in their house of joint family, but their marriage was made impossible after their unsuccessful attempt at eloping. Though Puran falls in love with Asha, he does not seem to have much boldness or the bravado to break class distinctions and marry the girl he truly loves. Meanwhile, Asha, who also reciprocates his love, understands that a marriage between them would never be possible because of social rules, where a rich man and poor woman can never get married. In the meantime, relatives try to fix Puran's marriage, but he does not respond or show his interest in marriage because of his undying love for Asha. While the poor Asha is in no control to take her life's decision in her own hands, regarding their marriage, Puran has the chance to break norms and defy society but instead of boldly declaring his love for Asha, he sits silently amidst all emotional turmoil that he and Asha both go through and he leaves his unsaid wishes at the mercy of his uncle and other relatives who finally understand whom he truly desires. Through turn of events and with the help of others, Asha who in is her way of departure, finally returns to him and they become united.

The movie, made in the 1940's, makes love and humanity triumph over social and economic class separations. Puran and Asha love each other and the movie fulfills their wishes, to encourage people in following the same path. However, one 
can question why Puran cannot be brave and bold enough to fight for his own rights. Why does he appear to be a pampered child who would not speak unless being wheedled? Had the movie shown a brave man fighting to be with a woman he loves, it would have had a much stronger point to motivate people, because like Puran, everybody shall not be fortunate enough to have supportive relatives or have lucky incidents happening in their lives that shall lead to the fulfilment of their wishes. Also, the movie gives an overall impression that a woman's goal and meaning in life is to only be concerned about being tied to the right man. Asha is seen as very submissive and coy, who dreams about Puran and sings and dances in joy on recalling him. Yet, she never confesses her love for him and also agrees to marry another man as others decide. Agreed, one should not expect such freedom of speech from a servant girl at that decade, but the shy, subtle behavior of Asha, her childish behaviour and almost purposeful act of helplessness in front of Puran, waiting to be rescued by him, are traits that prove that a woman is weak and all her energy should be invested in attracting and entertaining a man. Unfortunately, the situation has not changed much in the present times as well, where no matter how educated or financially independent Indian women are becoming, they still occupy most of their time with thoughts on how to get a man's attention and please him. In this situation, the fault lies more with women and not with men. If Indian women are so hellbent and devoted to entertaining men and win their attention, then it should not be men's fault if they demand more from women, as they see that women are willing to do just anything for them, by acquiescing to their wishes. In order to change this mentality of women, where they disrespect themselves, Indian movies should show bold women who love boldly, and besides loving a man, they have other engagements and occupations as well. Only then shall they truly attract men who 
will see a different kind of woman, who loves loving but does not pretend to be a damsel in distress, waiting to be rescued. Nevertheless, the important lesson that one should take in from the movie, is the possibility that love shall win in the end and that marriage should take place where hearts meet, not where society's rules are met.

\subsection{Pyaasa (Thirsty, Wistful), Guru Dutt, 1957}

With these movies bring chosen from the 1930's, 1940's and 1950 's, we shall notice the boldness with which women speak their minds and make themselves "heard". In Pyaasa (Thirsty, Wistful), a 146-minute, this 1957-movie talks about a very kind-hearted prostitute, who takes care of a fallen poet, who fails to grapple with harsh reality and survive in a very hostile world. The movie was written by Abrar Almi and directed and produced by Guru Dutt and, where he also was in one of the lead roles, along with Waheeda Rehman in the other lead role, and besides the movie had Mala Sinha. Notable singer R. D. Burman had sung the songs, which were written by lyricist Sahir Ludhhiyanvi.

In this story, Vijay - a poet and a wanderer with a streak of bohemian nature, encounters Gulabo, a prostitute, who is very loving, caring and kind. Vijay is a poet who is often disdained by his brothers and considered as not worthy of anything since he does not make any income or earn a fixed salary. Gulabo buys Vijay his meals and helps him by providing him with few other needs because she recognizes his talents and secretly falls in love with him. While Vijay is not careful about where he writes his poems and saves the papers, Gulabo carefully and impeccably collects pages of his poetries and get them published, without Vijay;'s knowledge. Vijay's past lover, Meena's husband, who is a publisher, publishes his poems because he is jealous of Meena's undying love for Vijay and wants to avenge Vijay by slyly and secretly publishing the 
poems without referencing him or without giving him any credit. Meanwhile, Vijay, who is recovering in a hospital, is oblivious of the fact that his poems have been published and have become successful. The publisher and Vijay's brothers decide to declare him dead to the world, as the brothers secretly want some money that has been made by publishing his poems. When Vijay finally gets to know the truth, he becomes sick and weary of the world, sick with the cruel machinations of human minds and leaves the corrupted place forever, somewhere we do not know, but he takes Gulabo with him, to make a new living where they can live away from cheaters and impostors.

Though Vijay is shown as the main protagonist in the movie, Gulabo is no less of another leading protagonist as well, since she is Vijay's saviour. Though at the end of the movie, Vijay is shown to be taking Gulabo along with him, wherever he is going, it was Gulabo who rescued Vijay throughout the movie. In this movie, both Gulabo rescues Vijay and Vijay rescues Gulabo where together as an unison they tread a path with hopes of being in a better place where the world shall be honest and kind. In most movies that show women being rescued by men, a woman here rescues a man. From helping Vijay, to befriending him, to giving him company and collecting his poems and publishing them, it is Gulabo's efforts that help Vijay to survive in a cruel, cheating world. Vijay is moody and whimsical, and he also lacks in enough strength to survive in a world full of hypocrisy, cruelty and falsity and depends on Gulabo's willpower where she is a fighter, because being a prostitute, she knows the hard way of life and is aware of a harsh world and well acquainted with it. She has the courage to keep fighting and to see positivity in living, despite how much people try to ruin another's life and to steal their peace. She shows Vijay the way to live life with hopes of a little better and brighter future. The film focuses on 
how, an otherwise simple prostitute, whom society considers as dirty, immoral and impure, is actually in truth an extremely humane and kind-hearted being, who instills hope and courage in others, to confront fraudulent and cheating people in a cruel world and through all battles in life, ultimately emerge as victorious, to prove that honesty wins in the end.

\section{Analysis and Conclusions: The Trends}

As it has been shown, the movies from 1930 to 1960 have been very realistic, where they reflected the Indian society as it was and situated women in a pragmatic light. The films had highlighted social causes like the caste system in the movie Achhut Kanya, marriage of young girls to old men in Duniya $\mathrm{Na}$ Mane, and economic, social and emotional hardship poor women face in the movie Aurat. The movie, Ziddi, also brings about an exception to the norms in society where a marriage between a rich man and a poor woman is made possible despite the inherent class system in India, where feudalism and the feudal mentality till date, forbids such a wedding from taking place. Also, we see an exemplary movie, Pyaasa that glorifies the benevolent nature of a prostitute who is not immoral and impure but - on the contrary, is extremely benevolent and caring. The movie does justice to prostitutes, who are otherwise ostracized from society and considered impure and immoral beings, who should only serve for the purpose of pleasing men.

One wonders if movie makers today are solely concerned with publicity and money making, and they get the hint that movies that celebrate women's freedom or show women in a positive light would not be a commercial hit. There does not seem to be a market survey of this kind showing such trends. On the contrary, the public reaction to mishaps against helpless women has been quite strident. And yet, to write novels or to make movies that commodify women have become a trend 
now so that women are mocked and harshly demeaned. The directors from the early age, as well as the producers of these movies, were devoted to a cause to better the society, especially because India was not yet an independent country or was becoming newly formed with a new democracy that granted voting rights to women immediately unlike some of the western democracies. Everybody longed for independence and wanted the society to be reformed. This agenda was reflected in our writing as well as in films. The movie industry had their ethics as well. In Hansa Wadkar's ${ }^{12}$ popular autobiographical book, YOU ASK, I TELL ${ }^{13}$ (2013) she shared her sorrow regarding the degrading standards of Indian movies where it was no longer respected as "art". She said "All those loath some affair during lunchtime and in the make-up room! We also misbehaved but never on the sets or in the make-up room. I have never betrayed art. I have always respected the dignity of the goddess of art" (Wadkar, 2013: 98 \& 99). On the question of how she perceived cinema as an art, where bars cannot be set to make an estimation of whether it is good art or perfect art, she said, "Can art ever attain perfection? The word kala $^{14}$ itself means to grow. Many do not know this, nor do they try to realise this. If somebody makes them realize this, they are irritated" (Wadkar 2013: 100). While in earlier days, cinema was an art form and actresses and actors revered it as an art which should benefit society and in no way should bring

${ }^{12}$ Hansa Wadkar was a popular Marathi actress who also acted in many early days Bollywood movies in the 1930's and 1940's.

${ }^{13}$ YOU ASK, I TELL (2013) is an autobiographical book based on the life of actress Hansa Wadkar, which was initially written in Marathi in 1970 under the name Sangtye Aika, which in trun was based on her interviews which were taken in 1966 by the journalist Arun Sadhu and published in the Marathi magazine Manoos. The Marathi book and the interviews were edited by Jasbir Jain and translated Shobha Shinde into English.

${ }^{14}$ The Sanskrit/Hindi words Kala, means "Art". 
harm upon women, the modern world has forgotten morality, rationality and values, and would do anything just for the sake of "money". The argument of trash authors, yellow journalists and sexist film-makers remains the same, namely that the public wants to see women being degraded and exposed as flesh. In the name of liberty and freedom, their claim would be that the readers or viewers are being given what they demanded. Even with censor and criticism in the media, an individual cannot be forced to change his or her taste, because soft porn movies have their own clientele, and no amount of government control over TV channels, or on New Media or publications can resolve this issue to give back to women the respect they deserve.

The films under discussion here - based on the stories or fiction that emerged in Indian languages had projected every facet and aspects of societal problems where both the problems and women represented in the context of those problems appear very realistic, unlike most Indian and primarily Bollywood movies that were being produced since this era appeared to be highly unrealistic. Women as depicted in the film-versions of these stories appeared to be gentle, caring and dutiful who also know how to protest, who also know how to raise voice in the face of severe injustice, where they do not wait for men's approval to opine their thoughts.

Women in these three decades are often seen to be selfsacrificing, willing to give up on their lives for others' wellbeing. But one does not get to see the other picture where a man is sacrificing his own life for a woman or rescuing a woman. In overall, women have been represented positively in these movies. Even though initially, they might appear to be passive and shy, they are otherwise given the space to voice their opinion, where the audience is bound to listen to them. 
Both in the fiction of those days as well as in the film versions, these women also share considerable screen space with men and are not shown as "enticing objects", who grace the screen with few fleeting seconds, placed in obvious context of a man, in modern films. Ample Respect and Regard has been shown towards women in very early Indian movies from 1930 to 1960 which is completely missing in most of the films made after this period, mainly because the stories were a mere success formula to churn out objects of entertainment, and not as pieces of creation.

\section{References}

Classic Movie Box. 1937. Duniya Na Maane. Shanta Apte, Keshavrao Date, Vimala Vasishta, Classic Movie Box". Online: $\quad 17^{\text {th }} \quad$ May, 2015. $<$ https://www.youtube.com/watch?v=NhBZetYLi9c>.n.pag e.

Feel Good Movies. Achhut Kanya 'Hindi Movie Full' I Classic Hindi Movie I Ashok Kumar, Devika Rani". Online: $\quad 2^{\text {nd }} \quad$ January, 2014. $<$ https://www.youtube.com/watch?v=9GIECFwR82g>.n.pa ge.

Golden FILMS. Pyaasa. Full Hindi Movie (HD), Popular Hindi Movies. Mala Sinha - Guru Dutt - Waheeda Rehman". Online: $21^{\text {st }} \quad$ April, 2017. $<$ https://www.youtube.com/watch?v=ieHt0AuGPfs>.n.page Golden FILMS. Ziddi. Full Hindi Movie, Popular Hindi Movies. Dev Anand - Kamini Kaushal - Chanda - Pran. youtube.com. Web. 23 $3^{\text {rd }}$ June, 2016. $<$ https://www.youtube.com/watch?v=iaur4u7Q0Bg>.n.page OlcotT, Mason. Dec 1944. The Caste System of India. American Sociological Review 9(6). 648-657. 
Anwita Maiti \& Udaya Narayana Singh

RADHAKRIShNAN, P.; and A. R. VASAVI. June $4^{\text {th }}, 1983$. Economics of Bride Price and Dowry. Economic and Political Weekly. 18(23), 1027-1028.

SANGTYE AIKA. 2015. You Ask, I Tell: An Autobiography by Hansa Wadkar (tr.) by Jasbir Jain and Shobha Shinde. Online: $8^{\text {th }}$

October, $<$ https://bagsbooksandmore.com/2015/10/08/sangtye-aikayou-ask-i-tell-an-autobiography-by-hansa-wadkar-translby-jasbir-jain-and-shobha-shinde/>.n.page.

Shemaroovintage. Aurat (Women) 1940. Sardar Akhtar Surendra. Bollywood Full Movie. Best Hindi Movie. Online: $\quad 6^{\text {th }} \quad$ July, 2015. <https://www.youtube.com/watch?v=MmdDYUxvM_0>.n. page.

SRINIVASAN, PADMA; and GARY. R. LEE. December 5 ${ }^{\text {th }}, 2004$. The Dowry System in Northern India: Women's Attitudes and Social Change. Journal of Marriage and Family, 66(5), Special Issue: International Perspectives on Families and Social Change. 1108-1117.

WADKAR, Hansa; JASBIR JaIn; and ShOBha SHINDE. 2013. You Ask, I Tell. New Delhi: Zubaan. ISBN: 9789381017 722. 